\title{
Exploring the ceiling effect of the revised Childhood Health Assessment Questionnaire in a European patient sample W Groen ${ }^{1}$, J Van der Net*1, M Nørgaard ${ }^{3}$, E Yakut ${ }^{2}$, K Berggren ${ }^{7}$, E Sandstedt ${ }^{8}$, $\mathrm{J} \mathrm{Scott}^{5}$, S Maillard ${ }^{4}$ and L Dougan ${ }^{6}$
}

Address: ${ }^{1}$ University Children's Hospital, Utrecht, Netherlands, ${ }^{2}$ Hacattepe University, School of Physical Therapy and rehabilitation, Ankara, Turkey, ${ }^{3}$ Deptartment of Physiotherapy, Århus University Hospital, Skejby, Århus, Denmark, ${ }^{4}$ Institute of Child Health, Great Ormond Street Childrens Hospital, London, UK, ${ }^{5}$ Birmingham Children's Hospital NHS foundation trust, Birmingham, UK, ${ }^{6}$ Royal Hospital for Sick Children, Glasgow, UK, ${ }^{7}$ Astrid Lindgren Children's Hospital, Karolinska University Hospital, Stockholm, Sweden and ${ }^{8}$ Queen Silvia Children's Hospital, Göteborg, Sweden

* Corresponding author

from 15th Paediatric Rheumatology European Society (PreS) Congress

London, UK. 14-17 September 2008

Published: 15 September 2008

Pediatric Rheumatology 2008, 6(Suppl I):PI02 doi:I0.II86/I546-0096-6-SI-PI02

This abstract is available from: http://www.ped-rheum.com/content/6/SI/PI02

(c) 2008 Groen et al; licensee BioMed Central Ltd.

\section{Background}

The original version of the Childhood Health Assessment Questionnaire (CHAQ30orig) suffers from a ceiling effect and hence has reduced clinical validity [1]. The effect of adding eight more demanding items and a new continuous response option (CATII) was tested.

\section{Methods}

Twenty-four children with JIA [2] were recruited from eight centres across Europe. Demographic, clinical, and CHAQ data were obtained. Five different score calculations were applied: the original method (CHAQ30orig), and the mean item scores for the 30 and 38-question versions with two categorical response options (Chaq30item CAT I and II and Chaq38item CAT I and II).

Descriptive statistics were calculated and CHAQ-data were tested for normality. A ceiling effect was defined by $15 \%$ or more patients scoring the best possible score.

\section{Results}

(preliminary, based on $30 \%$ of total data).

A ceiling effect was observed in CHAQ30orig and CHAQ30item (20.8\% for both). The median scores, KSstatistics, p-values, and interquartile range (IQR) are presented in table 1.

\section{Discussion}

The CHAQ38 with CATII scoring showed best overall distribution characteristics: no ceiling effect, more normally distribution, and the second largest IQR. (In September 2008 final results are presented).

\section{References}

I. Lam C, Young N, Marwaha J, Mc Limont M, Feldman BM: Revised Versions of the Childhood Health Assessment Questionnaire (CHAQ) Are More Sensitive and Suffer Less From a Ceiling Effect. Arthritis \& Rheumatism (Arthritis Care \& Research) 2004, 5 I:88I-889.

2. Petty RE, Southwood TR, Manners P, Baum J, Glass DN, Goldenberg J, He X, Maldonado-Cocco J, Orozco-Alcala J, Prieur AM: International League of Associations for Rheumatology classification of juvenile idiopathic arthritis: second revision, Edmonton, 200 I. J Rheumatol 2004, 3 I:390-392. 
Table I: Median, ceiling effect, KS results, and interquartile range of five CHAQ scoring methods.

\begin{tabular}{lllllll}
\hline & Scoring method & Median (range) & Ceiling effect (\%) & KS-statistic & P-value & IQR \\
\hline \multirow{2}{*}{ Cat I } & Chaq30orig & $0.81(0-2.13)$ & $20.8^{*}$ & 0.87 & 0.43 \\
& Chaq30item & $0.36(0-1.04)$ & $20.8^{*}$ & 0.87 & 1.38 \\
\multirow{4}{*}{ Cat II } & Chaq38item & $0.38(0-1.26)$ & 8.3 & 0.86 & 0.50 \\
& Chaq30item & $-0.24(-1.26-0.40)$ & 0 & 0.84 & 0.45 \\
& Chaq38item & $-0.34(-1.26-0.42)$ & 0 & 0.69 & 0.49 & 0.48 \\
& & & & 0.73 & 0.64 \\
\hline
\end{tabular}

Publish with Biomed Central and every scientist can read your work free of charge

"BioMed Central will be the most significant development for disseminating the results of biomedical research in our lifetime. " Sir Paul Nurse, Cancer Research UK

Your research papers will be:

- available free of charge to the entire biomedical community

- peer reviewed and published immediately upon acceptance

- cited in PubMed and archived on PubMed Central

- yours - you keep the copyright 